\title{
Understanding global secondary organic aerosol amount and size-resolved condensational behavior
}

\author{
S. D. D'Andrea ${ }^{1,2}$, S. A. K. Häkkinen ${ }^{3,4}$, D. M. Westervelt ${ }^{5}$, C. Kuang ${ }^{6}$, E. J. T. Levin ${ }^{2}$, V. P. Kanawade ${ }^{7}$, W. \\ R. Leaitch ${ }^{8}$, D. V. Spracklen ${ }^{9}$, I. Riipinen ${ }^{10}$, and J. R. Pierce ${ }^{2,1}$ \\ ${ }^{1}$ Department of Physics and Atmospheric Science, Dalhousie University, Halifax, Nova Scotia, Canada \\ ${ }^{2}$ Department of Atmospheric Science, Colorado State University, Fort Collins, CO, USA \\ ${ }^{3}$ Department of Physics, University of Helsinki, Helsinki, Finland \\ ${ }^{4}$ Department of Chemical Engineering, Columbia University, New York, NY, USA \\ ${ }^{5}$ Center for Atmospheric Particle Studies, Carnegie Mellon University, Pittsburgh, PA, USA \\ ${ }^{6}$ Atmospheric Sciences Division, Brookhaven National Laboratory, Building 815E, Upton, NY, USA \\ ${ }^{7}$ Department of Civil Engineering, Indian Institute of Technology, Kanpur, India \\ ${ }^{8}$ Environment Canada, Toronto, Ontario, Canada \\ ${ }^{9}$ School of Earth and Environment, University of Leeds, Leeds, UK \\ ${ }^{10}$ Department of Applied Environmental Science and Bert Bolin Centre for Climate Research, Stockholm University, \\ Stockholm, Sweden
}

Correspondence to: S. D. D’Andrea (sdandrea@atmos.colostate.edu)

Received: 20 June 2013 - Published in Atmos. Chem. Phys. Discuss.: 16 July 2013

Revised: 21 October 2013 - Accepted: 29 October 2013 - Published: 27 November 2013

\begin{abstract}
Recent research has shown that secondary organic aerosols (SOA) are major contributors to ultrafine particle growth to climatically relevant sizes, increasing global cloud condensation nuclei $(\mathrm{CCN})$ concentrations within the continental boundary layer (BL). However, there are three recent developments regarding the condensation of SOA that lead to uncertainties in the contribution of SOA to particle growth and CCN concentrations: (1) while many global models contain only biogenic sources of SOA (with annual production rates generally $10-30 \mathrm{Tg} \mathrm{yr}^{-1}$ ), recent studies have shown that an additional source of SOA around $100 \mathrm{Tg} \mathrm{yr}^{-1}$ correlated with anthropogenic carbon monoxide (CO) emissions may be required to match measurements. (2) Many models treat SOA solely as semi-volatile, which leads to condensation of SOA proportional to the aerosol mass distribution; however, recent closure studies with field measurements show nucleation mode growth can be captured only if it is assumed that a significant fraction of SOA condenses proportional to the Fuchs-corrected aerosol surface area. This suggests a very low volatility of the condensing vapors. (3) Other recent studies of particle growth show that SOA condensation deviates from Fuchs-corrected surface-area con-
\end{abstract}

densation at sizes smaller than $10 \mathrm{~nm}$ and that size-dependent growth rate parameterizations (GRP) are needed to match measurements. We explore the significance of these three findings using GEOS-Chem-TOMAS global aerosol microphysics model and observations of aerosol size distributions around the globe. The change in the concentration of particles of size $D_{\mathrm{p}}>40 \mathrm{~nm}$ (N40) within the BL assuming surface-area condensation compared to mass-distribution net condensation yielded a global increase of $11 \%$ but exceeded $100 \%$ in biogenically active regions. The percent change in N40 within the BL with the inclusion of the additional $100 \mathrm{Tg} \mathrm{SOA} \mathrm{yr}^{-1}$ compared to the base simulation solely with biogenic SOA emissions (19 $\mathrm{Tg} \mathrm{yr}^{-1}$ ) both using surface area condensation yielded a global increase of $13.7 \%$, but exceeded $50 \%$ in regions with large $\mathrm{CO}$ emissions. The inclusion of two different GRPs in the additional-SOA case both yielded a global increase in N40 of $<1 \%$, however exceeded $5 \%$ in some locations in the most extreme case. All of the model simulations were compared to measured data obtained from diverse locations around the globe and the results confirmed a decrease in the model-measurement bias and improved slope for comparing modeled to measured CCN 
number concentration when non-volatile SOA was assumed and the extra SOA was included.

\section{Introduction}

Atmospheric aerosols affect both health and climate. These health and climate effects depend directly on aerosol size and composition. Atmospheric aerosols can influence the climate by scattering incoming solar radiation (Rosenfeld et al., 2008; Clement et al., 2009) as well as acting as nuclei for cloud droplets (Charlson et al., 1992). The influence of aerosols on clouds is driven by the number concentration of cloud condensation nuclei (CCN) (particles on which cloud droplets form generally having dry diameters larger than $30 \mathrm{~nm}$ to $100 \mathrm{~nm}$ ), which is highly dependent on the aerosol size distribution (Dusek et al., 2006; McFiggans et al., 2006; Petters and Kriedenweis, 2007; Pierce and Adams, 2007). Aerosol nucleation, the formation of $\sim 1 \mathrm{~nm}$ diameter particles from the clustering of vapors, is likely the dominant source of aerosol number to the atmosphere (Kulmala et al., 2004). However, these particles must grow to CCN sizes, primarily through condensation, in order to affect climate (Pierce and Adams, 2007; Vehkamäki and Riipinen, 2012). Whether or not these particles survive to $\mathrm{CCN}$ sizes depends on the competition between condensational growth and coagulational scavenging with the pre-existing aerosol (Kerminen and Kulmala, 2002; Pierce and Adams, 2007; Kuang et al., 2009; Westervelt et al., 2013). Thus, faster particle growth rates allow more particles to survive to $\mathrm{CCN}$ sizes.

The condensation of sulfuric acid to freshly nucleated particles is known to be a contributor to the growth of these particles (Sipilä et al., 2010). In recent studies by Riipinen et al. (2011), measured growth rates of ultrafine (diameters smaller than $100 \mathrm{~nm}$ ) particles in forested regions were much higher than maximum growth rates from sulfuric acid alone. They found through a combination of measurements and modeling that the condensation of low-volatility secondary organic aerosols (SOA) can account for this additional growth. Measurements of the submicron particle composition throughout the continental boundary layer show 20 $90 \%$ of the aerosol is organic, and much of this organic aerosol is SOA (Jimenez et al., 2009). Thus we expect that SOA may be a significant contributor to ultrafine particle growth throughout the continental boundary layer. However, there are uncertainties regarding SOA and its contribution to ultrafine particle growth, and these will be explored in this paper. Additionally, SOA has recently been found to be involved in aerosol nucleation (Metzger et al., 2010), although this will not be a focus of this paper.

There are two important, but uncertain, characteristics of SOA that influence ultrafine particle growth: (1) the amount of SOA formed (or the rate at which it is formed) (Spracklen et al., 2011b; Heald et al., 2011) and (2) the condensational behavior of SOA (how SOA condenses to ultrafine particles)
(Riipinen et al., 2011; Pierce et al., 2011; Häkkinen et al., 2013; Kuang et al., 2012).

Regarding the uncertain amount of SOA, the global budget of SOA is highly unconstrained with bottom-up and top-down estimates ranging from 12 to $1820 \mathrm{Tg}(\mathrm{SOA}) \mathrm{yr}^{-1}$ (Goldstein and Galbally, 2007; Hallquist et al., 2009; Kanakidou et al., 2005). This uncertainty in the amount of condensing SOA available has important implications on the growth of ultrafine particles as well. Many global models only contain biogenic sources of SOA (and small contributions from anthropogenic SOA) with emissions generally between 10 and $30 \mathrm{Tg} \mathrm{yr}^{-1}$ (Pierce et al., 2011; Spracklen et al., 2006; Wainwright et al., 2012), on the low end of the uncertainty range. However, by comparing GLOMAP global model simulations to aerosol mass spectrometer measurements or organic aerosol mass, Spracklen et al. (2011b) were able to significantly improve the model prediction of organic aerosol mass by adding an additional $100 \mathrm{Tg} \mathrm{yr}^{-1}$ of SOA spatially correlated with anthropogenic carbon monoxide (CO) emissions. That additional SOA increases the amount of condensable material in the atmosphere, which increases growth rates of ultrafine particles; however, the extra mass also increases the condensation and coagulation sinks of small particles, which will slow their growth rates and increase their coagulational losses. Thus, it is unclear what overall effect the extra SOA will have on CCN.

Regarding the uncertain condensational behavior, many models treat a large fraction of SOA as semi-volatile (average saturation vapor concentration, $C^{*}>\approx 10^{-1} \mu \mathrm{g} \mathrm{m}^{-3}$ ) and follow the partitioning theory of Pankow (1994) (e.g. Lane and Pandis, 2007). These semi-volatile species reach equilibrium between the particle and gas phases for all particle sizes quickly, which leads to net condensation of SOA proportional to the aerosol mass distribution (Pierce et al., 2011; Riipinen et al., 2011; Donahue et al., 2011). This limit of net condensation of SOA to the mass distribution is called "thermodynamic condensation" by Riipinen et al. (2011) and we will use this terminology here. This causes preferential condensation of the organic mass to particles with $D_{\mathrm{p}}>100 \mathrm{~nm}$. This preferential net condensation to accumulation mode particles not only limits the amount of condensation to ultrafine particles, but also enhances the coagulational scavenging of the ultrafine particles by the larger diameter accumulation mode particles. These two factors decrease the survival probability of ultrafine particles and hence can lead to a low influence of nucleation and other ultrafine particles on CCN. However, recent closure studies with field measurements show that observations of nucleation-mode growth can only be explained if a significant fraction of SOA condenses proportional to the Fuchs-corrected aerosol surface area. This suggests that particles of all sizes are not in equilibrium with the vapor phase and that all particles are undergoing kinetic, gas-phase-diffusion-limited growth (referred to as "kinetic condensation" by Riipinen et al. (2011) and we will use this terminology here). In order for this purely 
kinetic condensation to occur, the condensing SOA has very low effective volatility $\left(C^{*}<\approx 10^{-3} \mu \mathrm{g} \mathrm{m}^{-3}\right)$ created either through gas-phase chemistry, particle-phase chemistry or trapping of semi-volatile species in the particle phase by a semi-solid shell (Donahue et al., 2011; Pierce et al., 2011; Riipinen et al., 2011; Zhang et al., 2012). This kinetic condensation enables condensation of more organic mass to ultrafine aerosols compared to thermodynamic condensation. An important characteristic of this pure kinetic condensation is that all particles in the kinetic regime (diameters smaller than about $50 \mathrm{~nm}$ ) grow at the same rate $\left(\mathrm{e} . \mathrm{g} . \mathrm{nm} \mathrm{h}^{-1}\right)$. On the other hand, under thermodynamic condensation, the growth rate scales with $1 / D_{\mathrm{p}}$. Thus, under kinetic condensation, ultrafine particles grow more quickly to climatically relevant sizes where they can act as CCN compared to thermodynamic condensation. In summary, thermodynamic condensational behavior assumes that the gas-particle partitioning reaches equilibrium instantly which means that the net particle condensation is proportional to the particle mass. This assumes SOA to be semi-volatile (e.g. $C^{*} \sim 1 \mu \mathrm{g} \mathrm{m}^{-3}$ ) where the SOA mass reaches thermodynamic equilibrium quickly and partitions into the pre-existing aerosol mass. Kinetic condensational behavior is limited by gas-phase-diffusional growth and thus vapors condense kinetically proportional to the aerosol surface area. This assumes SOA to be effectively non-volatile (e.g. $C^{*}<10^{-3} \mu \mathrm{g} \mathrm{m}^{-3}$ ). This is explored in detail in Riipinen et al. (2011) and Pierce et al. (2011). The reality is somewhere between these two limiting approaches for real compounds with finite saturation vapor pressures, and recent studies have explored this and are discussed in the next paragraph.

Two recent studies by Häkkinen et al. (2013) and Kuang et al. (2012) have shown that while particles at most diameters undergo kinetic (surface-area-limited) SOA condensational growth, the smallest (diameters less than 10 or $20 \mathrm{~nm}$ ) particles do not grow as fast as the larger particles (see also Manninen et al., 2010; Yli-Juuti et al., 2011). This means that some SOA species are not readily condensing to the smallest particles (likely because of Kelvin effects or Raoult's Law, Pierce et al., 2011). Häkkinen et al. (2013) used long-term size-dependent growth-rate observations at six sites in Europe and developed a size-dependent growth rate parameterization to slow the growth of the smallest particles during kinetic SOA condensation. The authors found that the growth rate begins to slow for diameters smaller than $7 \mathrm{~nm}$, and that the growth of $1 \mathrm{~nm}$ particles due to SOA is approximately 3 times slower than at sizes larger than $7 \mathrm{~nm}$. Furthermore, Häkkinen et al. (2013) also found indications of the importance of non-biogenic SOA in growing freshly formed nanoparticles at the continental sites they investigated (e.g. the anthropogenically influenced SOA from Spracken et al. (2011b) and Heald et al., 2011). In an independent study, Kuang et al. (2012) measured size-dependent growth rates at two field sites to also determine how the growth rate slows for the smallest particles. These authors found that the growth rates were constant down to a diameter of approximately $3 \mathrm{~nm}$, which is a smaller size than found in Häkkinen et al. (2013). Kuang et al. (2012) found that the growth of $1 \mathrm{~nm}$ particles due to SOA is approximately 5 times slower than larger particles. It is notable that the studies by Häkkinen et al. (2013) and Kuang et al. (2012) were from different sites and the size ranges investigated were different. These size-dependent corrections to kinetic SOA condensation will influence growth rates and ultrafine particle survival to $\mathrm{CCN}$ sizes but have not yet been tested in global aerosol models.

In this study we use a global chemical transport model with online aerosol microphysics to test the sensitivity of the simulated aerosol size distributions to (1) the amount of available SOA, (2) SOA condensational methods (i.e. thermodynamic (mass) vs. kinetic (surface area) condensation), as well as (3) two size-dependent nanoparticle growth rate parameterizations that correct for errors due to assuming pure kinetic condensation. We then use global measurements of aerosol size distributions to test the model using various SOA assumptions. Our goals are to determine the sensitivities of $\mathrm{CCN}$ number concentrations to uncertainties in the SOA parameters and determine if we can constrain the parameter uncertainties using the measured size distributions.

\section{Methods}

In this paper, we use the global chemical-transport model, GEOS-Chem (http://geos-chem.org), combined with the online aerosol microphysics module, TOMAS (GEOS-ChemTOMAS) (as described in Pierce et al., 2013) to test the sensitivity of global aerosol size distributions to SOA condensational behavior, SOA amount, as well as size-dependent growth rate parameterizations. GEOS-Chem-TOMAS uses GEOS-Chem v8.02.02 (http://geos-chem.org) with a $4^{\circ} \times 5^{\circ}$ horizontal resolution, 30 vertical layers from the surface to $0.01 \mathrm{hPa}$ with meteorological inputs from the GEOS3 reanalysis (http://gmao.gsfc.nasa.gov). GEOS-Chem-TOMAS simulates the aerosol size distribution using 40 size sections ranging from $1 \mathrm{~nm}$ to $10 \mu \mathrm{m}$. Nucleation rates in all simulations were predicted by ternary homogeneous nucleation of sulfuric acid, ammonia and water based on the parameterization of Napari et al. (2002) scaled down globally by a constant factor of $10^{-5}$ which has been shown to predict nucleation rates closer to measurements than other commonly used nucleation schemes (Jung et al., 2010; Westervelt et al., 2013). Emissions in GEOS-Chem are described in van Donkelaar et al. (2008). We note that the predicted size distributions and uncertainty ranges in this paper are sensitive to the nucleation scheme, emissions fluxes and size of emitted particles (e.g. Pierce and Adams 2009b), but here we explore the modeled partial derivatives to SOA assumptions. Simulations were run for 2001 with one month of spin-up from a pre-spun-up restart file. We test the sensitivity of predicted 
size distributions to the condensational behavior of SOA in GEOS-Chem-TOMAS by assuming the kinetic and thermodynamic limits of SOA condensation. For thermodynamic condensation, we distribute the SOA across the aerosol sizes proportional to the aerosol mass distribution. For kinetic condensation, we distribute the SOA mass across the aerosol sizes proportional to the Fuchs-corrected aerosol surface area distribution (Donahue et al., 2011; Pierce et al., 2011; Riipinen et al., 2011).

Traditionally, SOA in GEOS-Chem-TOMAS is formed only from terrestrial biogenic sources, with the biogenic source being a fixed yield of $10 \%$ of the monoterpene emissions. This biogenic source of SOA represents an annual flux of $19 \mathrm{Tg}$ (SOA) $\mathrm{yr}^{-1}$. To test the sensitivity of GEOSChem-TOMAS to the amount of condensable SOA, we include $100 \mathrm{Tg}(\mathrm{SOA}) \mathrm{yr}^{-1}$ spatially correlated with anthropogenic $\mathrm{CO}$ emissions based on the findings of Spracklen et al. (2011b).

Finally, we test the sensitivity of GEOS-Chem-TOMAS to various nanoparticle size-dependent growth rate parameterizations that correct for deviation from the kinetic SOA condensation limit. The first parameterization implemented into GEOS-Chem-TOMAS is a linear fit based on the findings of Kuang et al. (2012) where the condensation rate of SOA is scaled down from the kinetic limit for particles with $D_{\mathrm{p}}$ of $1 \mathrm{~nm}$ to $2.5 \mathrm{~nm}$ based on their diameter using the following equation:

$k=0.47 D_{p}-0.18$

where $k$ is an empirical unitless condensation scale factor, a linear reduction in the size-dependent mass flux and growth rate (equal to 0.29 for $1 \mathrm{~nm}$ particles and 1 for $2.5 \mathrm{~nm}$ particles) and $D_{\mathrm{p}}$ is the diameter in $\mathrm{nm}$. Equation (1) was based on Fig. $1 \mathrm{~b}$ from Kuang et al. (2012). The other parameterization that we test in GEOS-Chem-TOMAS is based on the findings of Häkkinen et al. (2013) where a semi-empirical parameterization of condensation-rate scale factors was developed for sub-20 $\mathrm{nm}$ particles. This parameterization contains specific growth rates for particles in three diameter ranges $(1.5-3 \mathrm{~nm}$, $3-7 \mathrm{~nm}$ and $7-20 \mathrm{~nm}$ ). The growth rates have scaling factors of $k_{1.5-3 \mathrm{~nm}}=0.0, k_{3-7 \mathrm{~nm}}=0.7$ and $k_{7-20 \mathrm{~nm}}=1.0$. This set of scaling factors was calculated in Häkkinen et al. (2013) using data from six measurement sites in Europe.

\subsection{Description of simulations}

The various GEOS-Chem-TOMAS simulations in this study are summarized in Table 1. The BASE simulations include the biogenic SOA only with an annual flux of $19 \mathrm{Tg}(\mathrm{SOA}) \mathrm{yr}^{-1}$. The XSOA simulations include an additional $100 \mathrm{Tg}(\mathrm{SOA}) \mathrm{yr}^{-1}$ spatially correlated with anthropogenic CO emissions as per Spracklen et al. (2011b). The MASS simulations assume thermodynamic SOA condensation, which condenses to the aerosol size distribution proportional to the aerosol mass via thermodynamic conden- sation (Pierce et al., 2011; Riipinen et al., 2011; Zhang et al., 2012), while the SURF simulations assume kinetic SOA condensation, which condenses to the aerosol size distribution proportional to the Fuchs-corrected aerosol surface area (Donahue et al., 2011; Pierce et al., 2011; Riipinen et al., 2011; Zhang et al., 2012). The simulations including the linear sub- $2.5 \mathrm{~nm}$ size dependent growth rate parameterization (corrections to kinetic condensation) based on the findings of Kuang et al. (2012) are labeled with an additional "K". The simulations including the sub- $20 \mathrm{~nm}$ semi-empirical size dependent growth rate parameterization based on the findings of Häkkinen et al. (2013) are labeled with an additional "H". Note that we only perform size-dependent growth rate simulations with the SURF-XSOA assumptions. This is because the parameterizations are corrections for kinetic condensation (the SURF assumption), and the effect of the $\mathrm{K}$ and $\mathrm{H}$ parameterizations are stronger under the XSOA simulations.

\subsection{Description of measurements}

Surface-based particle size distribution measurements were compiled from the European Supersites for Atmospheric Aerosol Research (www.eusaar.net), from Environment Canada (Pierce et al., 2012; Riipinen et al., 2011; Leaitch et al., 2013), from the RoMANS 2 campaign (instrumentation and site descriptions are same as RoMANS 1 campaign as per Levin et al., 2009), from the BEACHON campaign (Levin et al., 2012) and from Kent State University (Kanawade et al., 2012; Erupe et al., 2010). In this study, 21 ground sites were selected (see Table 2 and Fig. 1) from Europe and North America. At each site, particle size distributions were measured with a Scanning Mobility Particle Sizer (SMPS) (Wang and Flagan, 1990) or a Differential Mobility Particle Sizer (DMPS) (Aalto et al., 2001) instrument. The characteristics of the sites include various terrain types such as coastal, mountain, boreal forest, arctic and rural environments. The air masses measured at each site also vary from polluted to remote continental and marine. However, we have intentionally avoided sites that are located in polluted urban areas as the coarse, $4^{\circ} \times 5^{\circ}$, resolution of the model cannot match these observations. Detailed information on each $\mathrm{Eu}-$ ropean site including location and observed particle number concentrations can be found in Asmi et al. (2011) and Reddington et al. (2011). Information from the North American sites can be found in Pierce et al. (2012), Riipinen et al. (2011), Leaitch et al. (2013), Levin et al. (2009), Levin et al. (2012), Kanawade et al. (2012) and Erupe et al. (2010).

\subsection{Numerical analysis of annual-mean size distributions}

We evaluate the quality of the model predictions by comparing the predicted, time-averaged aerosol number concentrations with various size cutoffs (e.g. the number concentration of particles with diameters larger than 10, 40,80 and $150 \mathrm{~nm}$ 


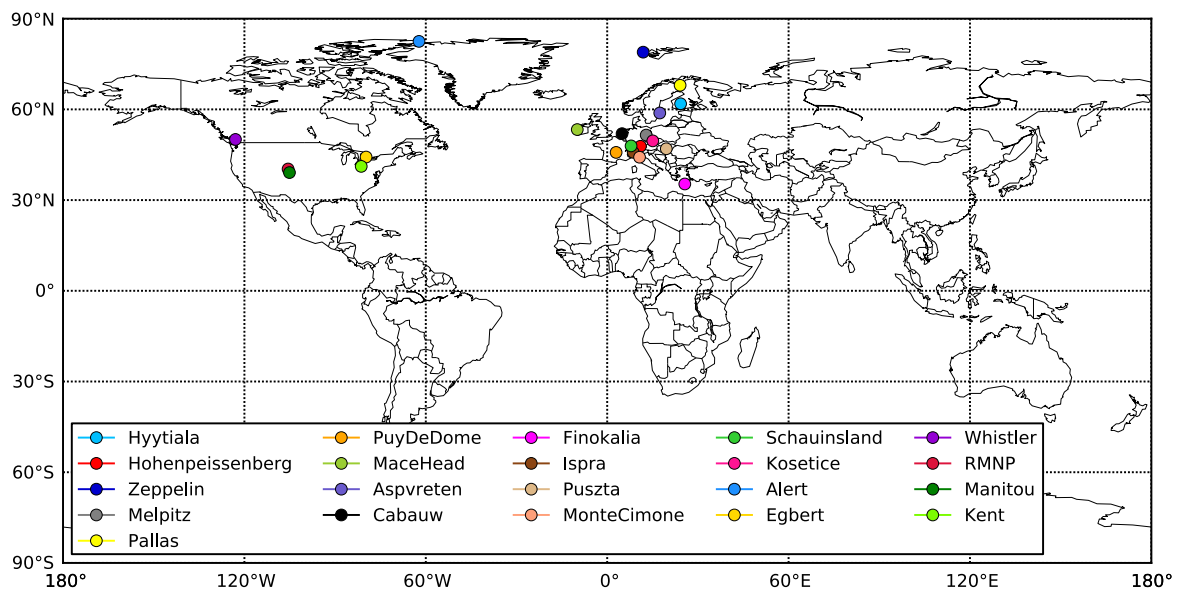

Fig. 1. Locations of the surface-based measurement sites used in this study.

Table 1. Summary of the GEOS-Chem-TOMAS simulations performed in this study.

\begin{tabular}{lllll}
\hline Simulation name & $\begin{array}{l}\text { Condensational } \\
\text { Behavior }\end{array}$ & $\begin{array}{l}\text { Additional 100 } \\
\operatorname{Tg}^{(S O A)} \mathrm{yr}^{-1}\end{array}$ & $\begin{array}{l}\text { Growth rate } \\
\text { parameterization } \\
\text { based on Kuang } \\
\text { et al. (2012) }\end{array}$ & $\begin{array}{l}\text { Growth rate } \\
\text { parameterization } \\
\text { based on Häkkinen } \\
\text { et al. (2013) }\end{array}$ \\
\hline MASS-BASE & Thermodynamic (mass) & no & no & no \\
SURF-BASE & Kinetic (surface area) & no & no & no \\
MASS-XSOA & Thermodynamic (mass) & yes & no & no \\
SURF-XSOA & Kinetic (surface area) & yes & no & no \\
SURF-XSOA-K & Kinetic (surface area) & yes & yes & no \\
SURF-XSOA-H & Kinetic (surface area) & yes & no & yes \\
\hline
\end{tabular}

[N10, N40, N80 and N150]) in the grid box and model level of each observational site to the time-averaged number concentration values of the observations. We time-average the model values over the months where measurements were taken. We only perform the time-average spatial analysis and do not perform a time-dependent analysis as our simulations do not necessarily correspond to the same year as the observations. We calculate three metrics to evaluate the model performance. The first is the log-mean bias (LMB) statistic:

$\mathrm{LMB}=\frac{\sum_{i}\left(\log _{10}\left(S_{i}\right)-\log _{10}\left(O_{i}\right)\right)}{N}$

where $S_{i}$ and $O_{i}$ are simulated and observed particle number concentrations, respectively for each ground site, $i$, and $N$ is the number of sites. A LMB of 1 means that the model overestimates, on average, by a factor of $10^{1}=10$, and a LMB of -2 means that the model underestimates, on average, by a factor of $10^{-2}=0.01$. The other two statistics are the correlation coefficient $\left(R^{2}\right)$ and the slope of the log-log regression $(m)$. The LMB, slope of the linear regression $(m)$ and coefficient of determination $\left(R^{2}\right)$ for each ground site, $i$, and simulation are plotted in Fig. 10 and summarized in Table 3.

\section{Results}

Figure 2 shows the base-case global annual-mean boundarylayer (BL) total number concentration of particles N3, N10, $\mathrm{N} 40$ and N80 (the total number concentration of particles with diameter larger than $3 \mathrm{~nm}, 10 \mathrm{~nm}, 40 \mathrm{~nm}$ and $80 \mathrm{~nm}$ respectively) when assuming semi-volatile SOA with condensation proportional to the aerosol mass distribution (MASSBASE). This figure may be used as a basis for the comparison figures that follow. In this paper, we will focus on the BL sensitivities since this is where the observations (with several exceptions) are located and also where the sensitivities of the size distribution to SOA are the highest.

\subsection{Sensitivity to SOA amount}

Figure 3 shows the global annual-mean percent changes in N3, N10, N40 and N80 throughout the BL between the simulation including an additional $100 \mathrm{Tg}$ (SOA) $\mathrm{yr}^{-1}$ correlated with anthropogenic CO emissions (SURF-XSOA) and the SURF-BASE case, both assuming non-volatile SOA (red denotes higher concentrations in the SURF-XSOA simulation). There was a global change of $-50.9 \%,-26.6 \%, 13.7 \%$ and 
Table 2. Summary of surface observation sites used in this study compiled from the European Supersites for Atmospheric Aerosol Research (www.eusaar.net), from Environment Canada (Pierce et al., 2012; Riipinen et al., 2011), from the RoMANS 2 campaign (Levin et al., 2009), from the BEACHON campaign (Levin et al., 2012) and from Kent State University (Kanawade et al., 2012; Erupe et al., 2010). This summary is based on a similar surface observation site summary from Reddington et al. (2011). All date ranges except Kent are for one complete year.

\begin{tabular}{|c|c|c|c|c|}
\hline Site name & Elevation (m a.s.l.) & Aerosol instrument & Year & Recorded Bin Size Range (nm) \\
\hline Alert, Canada & 200 & SMPS & 2012 & $10.4-469.8$ \\
\hline Aspvreten, Sweden & 30 & DMPS & 2005 & $11.1-417.8$ \\
\hline Cabauw, Netherlands & 60 & SMPS & 2008 & $9.4-516.0$ \\
\hline Egbert, Canada & 264 & SMPS & 2007 & $10.7-392.4$ \\
\hline Finokalia, Greece & 250 & SMPS & 2009 & $11.6-916.0$ \\
\hline Hohenpiessenberg, Germany & 980 & SMPS & 1999 & $3.0-678.4$ \\
\hline Hyytiälä, Finland & 181 & DMPS & 2001 & $3.2-501.0$ \\
\hline JRC-Ispra, Italy & 209 & DMPS & 2008 & $10.0-600.0$ \\
\hline K-puszta, Hungary & 125 & SMPS & 2006 & $5.6-1000.0$ \\
\hline Kent, USA & 320 & SMPS & 2008-2009 & $3.2-914.0$ \\
\hline Košetice, Czech Republic & 534 & SMPS & 2009 & $9.5-908.8$ \\
\hline Mace Head, Ireland & 5 & SMPS & 2008 & $8.3-467.5$ \\
\hline Manitou Experimental Forest, USA & 2300 & DMPS & 2010 & $15.6-354.3$ \\
\hline Melpitz, Germany & 87 & DMPS & 2004 & $3.0-802.1$ \\
\hline Monte Cimone, Italy & 2165 & DMPS & 2007 & $4.7-466.8$ \\
\hline Pallas, Finland & 560 & DMPS & 2001 & $7.4-494.2$ \\
\hline Puy de Dôme, France & 1465 & SMPS & 2007 & $3.0-995.0$ \\
\hline Rocky Mountain National Park (RMNP), USA & 2750 & DMPS & 2008 & $32.4-22909.0$ \\
\hline Schauinsland, Germany & 1205 & SMPS & 2008 & $10.0-800.0$ \\
\hline Whistler, Canada & 2182 & SMPS & 2011 & $14.1-572.5$ \\
\hline Zeppelin Mountain, Svalbard Islands & 474 & DMPS & 2001 & $20.1-635.1$ \\
\hline
\end{tabular}
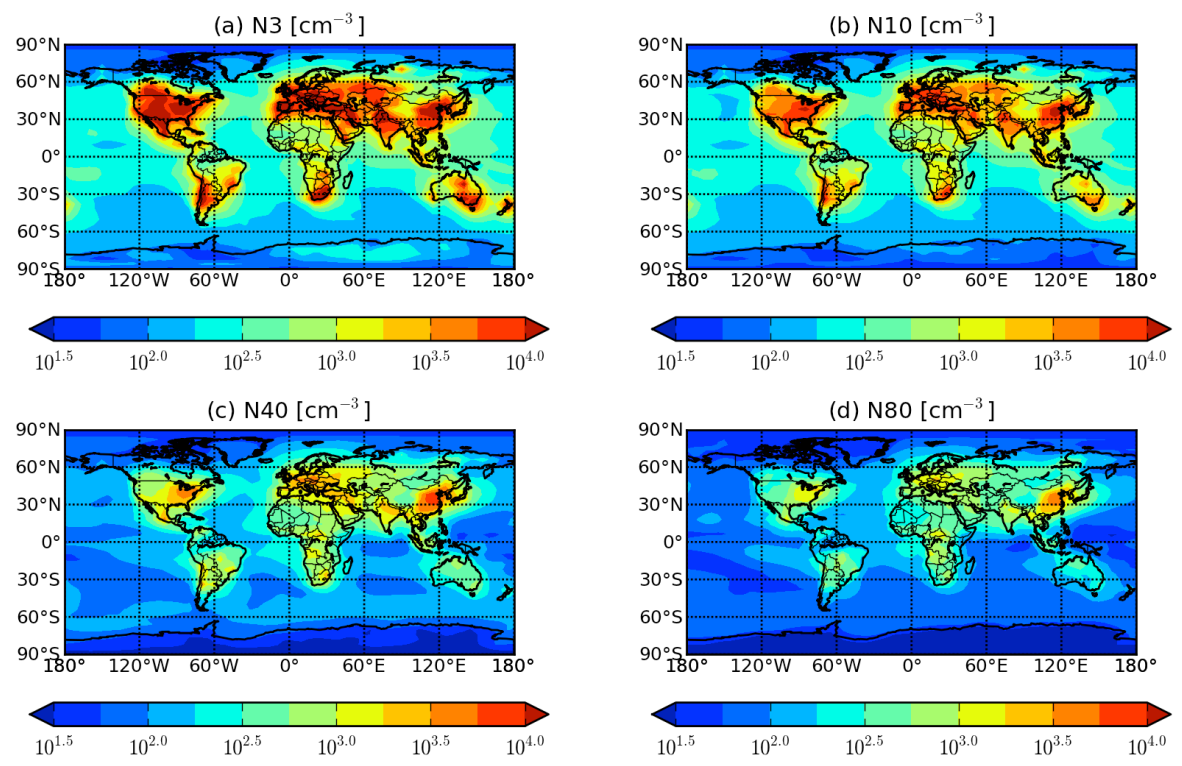

Fig. 2. Global annual-mean boundary-layer total number of particles (a) N3, (b) N10, (c) N40 and (d) N80 (the total number of particles with diameter larger than $3 \mathrm{~nm}, 10 \mathrm{~nm}, 40 \mathrm{~nm}$ and $80 \mathrm{~nm}$ respectively) for the MASS-BASE case. 
Table 3. Summary of the log-mean bias (LMB), slope of the linear regression $(m)$ and correlation $\left(R^{2}\right)$ for the different simulations. These statistics are found by comparing the annual-average values of the aerosol number concentrations across all sites. Bolded numbers represent the best statistical result between all simulations.

\begin{tabular}{l|rrrr|rrrr|rrrrr}
\hline Simulation & \multicolumn{4}{|c|}{ LMB } & \multicolumn{4}{|c}{$m$} & \multicolumn{4}{c}{$R^{2}$} \\
\hline & N10 & N40 & N80 & N150 & N10 & N40 & N80 & N150 & N10 & N40 & N80 & N150 \\
MASS-BASE & 0.203 & -0.047 & -0.099 & -0.199 & 1.031 & 0.825 & 0.729 & 0.628 & 0.91 & 0.90 & 0.86 & 0.80 \\
SURF-BASE & 0.203 & $\mathbf{- 0 . 0 3 5}$ & -0.083 & -0.181 & 1.025 & 0.827 & 0.732 & 0.633 & 0.91 & 0.90 & 0.86 & 0.80 \\
MASS-XSOA & 0.100 & -0.067 & -0.084 & -0.107 & $\mathbf{1 . 0 0 3}$ & 0.857 & 0.783 & 0.722 & $\mathbf{0 . 9 2}$ & $\mathbf{0 . 9 1}$ & 0.86 & 0.80 \\
SURF-XSOA & $\mathbf{- 0 . 0 3 0}$ & -0.052 & $\mathbf{0 . 0 0 5}$ & $\mathbf{0 . 0 7 1}$ & 0.888 & $\mathbf{0 . 8 7 6}$ & $\mathbf{0 . 8 5 9}$ & $\mathbf{0 . 8 5 2}$ & 0.89 & $\mathbf{0 . 9 1}$ & $\mathbf{0 . 8 7}$ & $\mathbf{0 . 8 2}$ \\
\hline
\end{tabular}
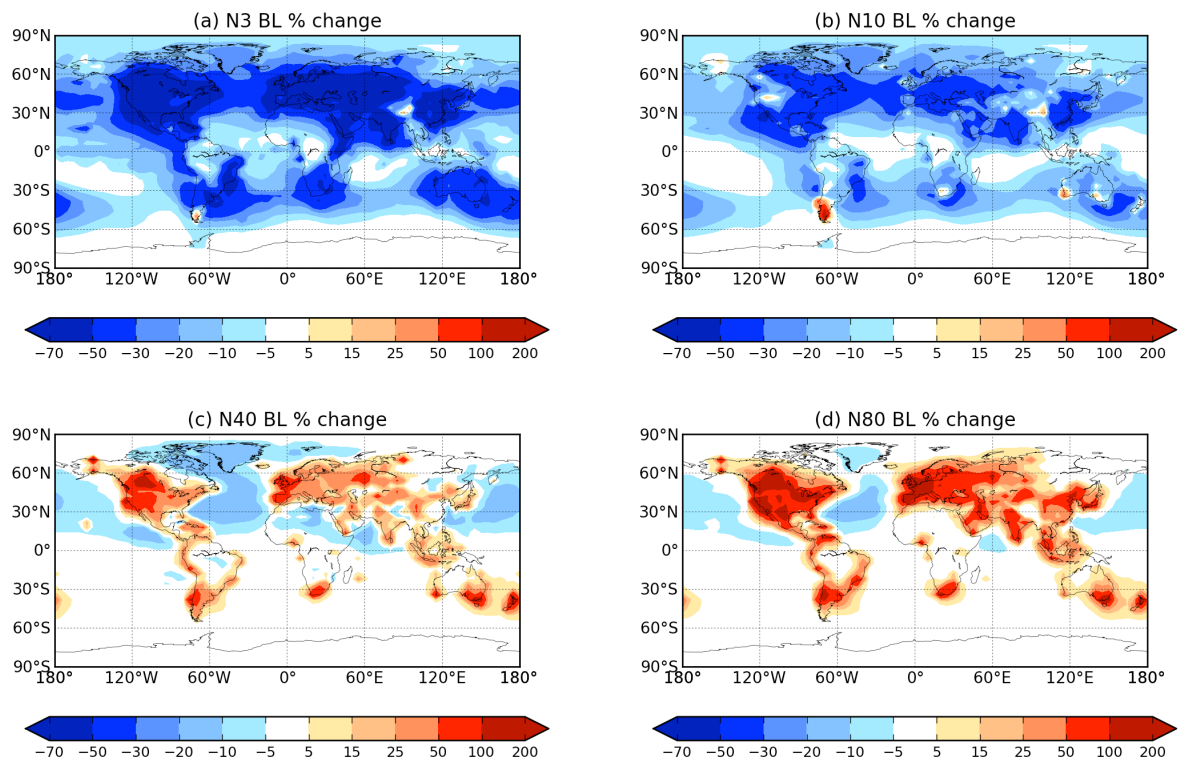

Fig. 3. Global annual-mean BL changes in (a) N3, (b) N10, (c) N40 and (d) N80 between SURF-BASE and SURF-XSOA (red denotes higher

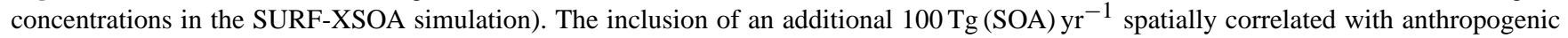
$\mathrm{CO}$ emissions (Spracklen et al., 2011b) caused global decreases in N3 and N10 of $50.9 \%$ and $26.6 \%$ respectively, however global increases of $13.7 \%$ and $29.9 \%$ in N40 and N80 respectively.

$29.9 \%$ in N3, N10, N40 and N80 respectively throughout the $\mathrm{BL}$. The decreases in N3 and N10 due to the extra SOA occur throughout most of the Northern Hemisphere and through the mid-latitudes of the Southern Hemisphere. The decreases in $\mathrm{N} 3$ are more than $70 \%$ throughout much of the globe. N40 and N80 show large increases due to the SOA in anthropogenic CO-source regions (over $100 \%$ increases in some regions), but smaller decreases downwind of these regions.

These increases and decreases are explained through a series of microphysical feedbacks. In anthropogenic $\mathrm{CO}$ source regions, there is a large increase in the amount of condensable SOA. This extra SOA grows more ultrafine particles to sizes larger than 40 and $80 \mathrm{~nm}$, thus causing the increase in N40 and N80 in the source regions in the SURF-XSOA case. However, this increase in the number of larger particles increases the condensation and coagulation sinks. This increase in the condensation sink is confirmed in Fig. 4 where the global annual-mean percent change in sulfuric acid vapor concentration between the same two cases is shown. There is a global decrease in sulfuric acid vapor of $18.8 \%$ (larger near many anthropogenic $\mathrm{CO}$ source regions) with the inclusion of the additional SOA since the condensation of sulfuric acid vapor increases with the increased number of large particles (increased condensation sink). The decrease in sulfuric acid causes a suppression of nucleation. Additionally, the increase in coagulational scavenging due to the increased coagulation sink of small particles further decreases the N3 and N10. However, as the air masses move away from the anthropogenic $\mathrm{CO}$ source regions, the $\mathrm{CCN}$-sized (N40 and N80) particles are lost by wet deposition more quickly than the smaller particles. In the SURF-BASE simulation (without the extra SOA), there are ultrafine particles that grow to $\mathrm{CCN}$ sizes and replace the lost $\mathrm{N} 40$ and N80; however, the SURF-XSOA simulation (with the extra SOA) has significantly fewer ultrafine particles to replace the lost N40 and N80. Thus, the SURF-XSOA simulation has lower N40 and 


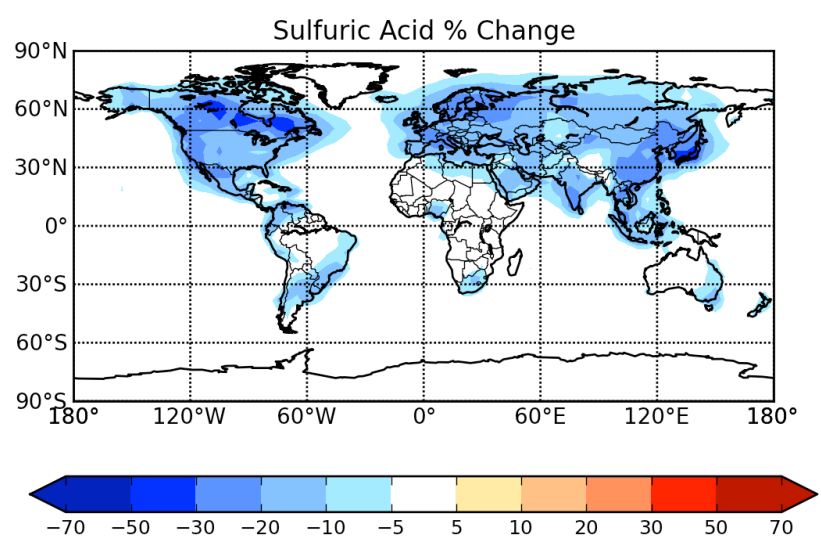

Fig. 4. Global annual-mean BL changes in sulfuric acid vapor concentration between SURF-BASE and SURF-XSOA. A global BL decrease of $18.8 \%$ was observed with the addition of an extra $100 \mathrm{Tg}(\mathrm{SOA}) \mathrm{yr}^{-1}$ spatially correlated with anthropogenic CO emissions (Spracklen et al., 2011b).

N80 concentrations over regions downwind of anthropogenic $\mathrm{CO}$ source regions (e.g. the North Atlantic and North Pacific oceans).

\subsection{Sensitivity to SOA condensational behavior}

Figure 5 shows the annual-average percent change in N3, $\mathrm{N} 10, \mathrm{~N} 40$ and $\mathrm{N} 80$ throughout the BL when switching from thermodynamic SOA condensation to kinetic SOA condensation under the biogenic-only SOA conditions (SURF-BASE - MASS-BASE). There was a global increase of $0.3 \%$, $5.2 \%, 10.8 \%$ and $8.7 \%$ in $\mathrm{N} 3, \mathrm{~N} 10, \mathrm{~N} 40$ and $\mathrm{N} 80$, respectively throughout the $\mathrm{BL}$, due to the SOA condensing more favorably to the ultrafine particles in the SURF-BASE simulation with the kinetic SOA condensation. In some regions downwind of biogenically active regions, N3 decreases by more than $10 \%$. The increased ultrafine particle growth in the biogenically active regions causes an increase in the coagulational sink for small particles and they are removed more quickly, therefore causing a deficiency in N3. As the air masses move over oceanic regions away from these regions, relatively few emitted or nucleated ultrafine particles are available to replace the lost N3. However, in many biogenically active regions, the increases in $\mathrm{N} 40$ and $\mathrm{N} 80$ (which we use in this study as a proxy for CCN) surpassed $15 \%$, and in the continental tropics the increase exceeded $100 \%$. Therefore, the predicted $\mathrm{CCN}$ concentrations are sensitive to the condensational behavior of SOA, consistent with the findings of Riipinen et al. (2011). As field studies (e.g. Riipinen et al., 2011; Pierce et al., 2011, 2012) have found that SOA condensation appears to be closer to the kinetic limit, the higher $\mathrm{CCN}$ values in the SURF-BASE simulation may be more appropriate, and we will evaluate this later.

\subsection{Sensitivity to size-dependent growth rate parameterizations}

\subsubsection{Sub-3 $\mathrm{nm}$ growth rate parameterization}

Figure 6 shows the global annual-mean percent changes in $\mathrm{N} 3, \mathrm{~N} 10, \mathrm{~N} 40$ and $\mathrm{N} 80$ throughout the BL assuming kinetic SOA condensation, the inclusion of the additional $100 \mathrm{Tg}$ (SOA) $\mathrm{yr}^{-1}$ as well as the implementation of the sub$2.5 \mathrm{~nm}$ growth rate correction to the kinetic condensation assumption based on the findings of Kuang et al. (2012) (SURF-XSOA-K) from the SURF-XSOA case (red denotes higher concentrations in the SURF-XSOA-K simulation). There was a global change of $-0.20 \%,-0.21 \%,-0.03 \%$ and $-0.01 \%$ in N3, N10, N40 and N80 throughout the BL respectively. This reduction in number concentrations is due to the decrease in the growth rate of sub- $2.5 \mathrm{~nm}$ particles and hence a slight increase in the coagulational scavenging of these nanoparticles before they can grow via condensation. In some regions, there was a decrease in N3 and N10 of greater than 5\%, however with this change in the growth rates of the sub- $2.5 \mathrm{~nm}$ particles, there is negligible change to N40 or N80. This negligible change to CCN sized particles shows that a small change in sub- $2.5 \mathrm{~nm}$ nucleation mode growth rates is dampened by the effects of aerosol microphysics (nucleation, condensation, coagulation and other processes that shape the aerosol number, size and composition).

\subsubsection{Sub-20 $\mathrm{nm}$ growth rate parameterization}

Figure 7 shows the global annual-mean percent changes in N3, N10, N40 and N80 throughout the BL assuming kinetic SOA condensation, the inclusion of the additional $100 \mathrm{Tg}(\mathrm{SOA}) \mathrm{yr}^{-1}$ as well as the inclusion of the semiempirical sub- $20 \mathrm{~nm}$ growth rate correction to the kinetic condensation assumption based on the findings of Häkkinen et al. (2013) (SURF-XSOA-H) from the SURF-XSOA case (red denotes higher concentrations in the SURF-XSOA-H simulation). There was a global change of $-5.8 \%,-4.4 \%$, $-1.0 \%$ and $-0.6 \%$ in $\mathrm{N} 3, \mathrm{~N} 10, \mathrm{~N} 40$ and $\mathrm{N} 80$ throughout the $\mathrm{BL}$ respectively. In some regions, there is a decrease in N3 and N10 of greater than 50\%. This semi-empirical sizedependent growth rate parameterization has a much greater effect on global particle number concentrations than the linear sub- $2.5 \mathrm{~nm}$ growth rate parameterization based on Kuang et al. (2012); however, even with non-negligible decreases in N3 and N10, the effect on global CCN concentrations remains small except for over some continental source regions. The sensitivity of N40 and N80 to changes in growth rates of sub- $20 \mathrm{~nm}$ particles has been shown to be highly dampened due to other microphysical processes and the effects are much smaller than the other SOA assumptions tested earlier. 

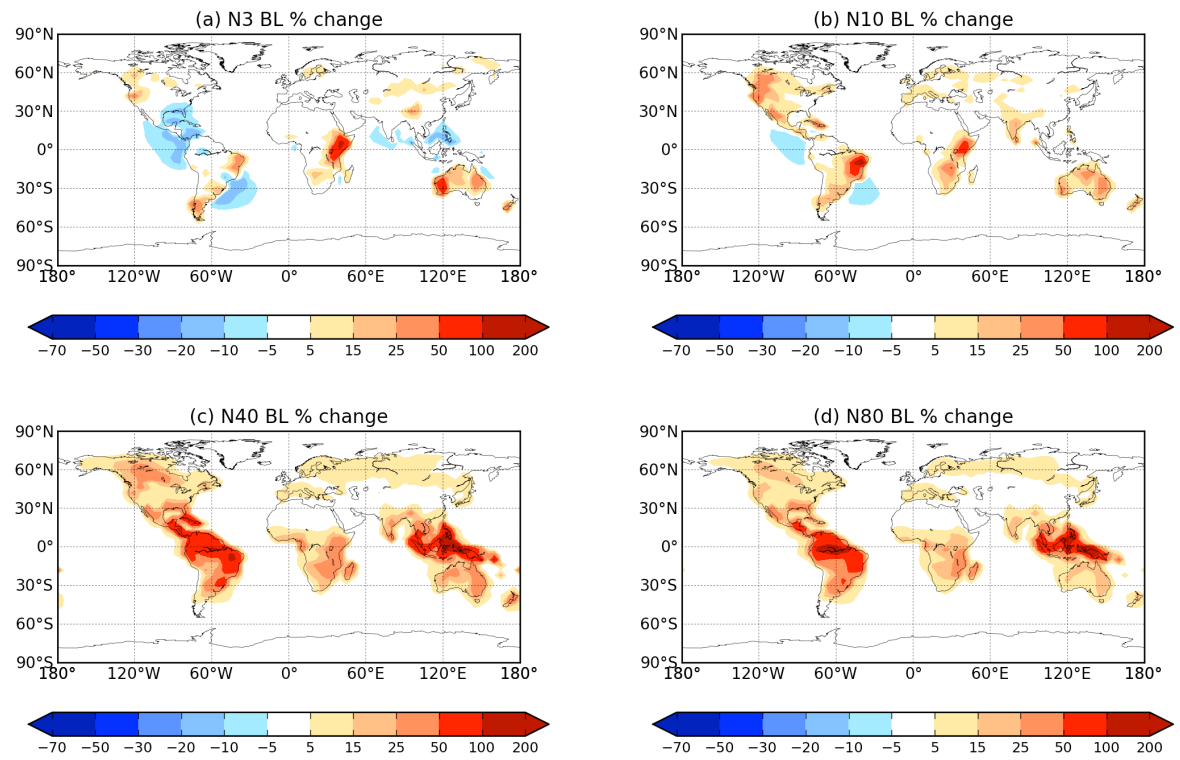

Fig. 5. Global annual-mean boundary-layer changes in (a) N3, (b) N10, (c) N40 and (d) N80 between MASS-BASE and SURF-BASE (red denotes higher concentrations in the SURF-BASE simulation). There was a global BL increase of $0.3 \%, 5.2 \%, 10.8 \%$ and $8.7 \%$ in N3, $\mathrm{N} 10, \mathrm{~N} 40$ and N80 respectively when assuming kinetic condensation. Regions which are biogenically active indicate increases greater than $50 \%$ in $\mathrm{N} 40$ and $\mathrm{N} 80$.
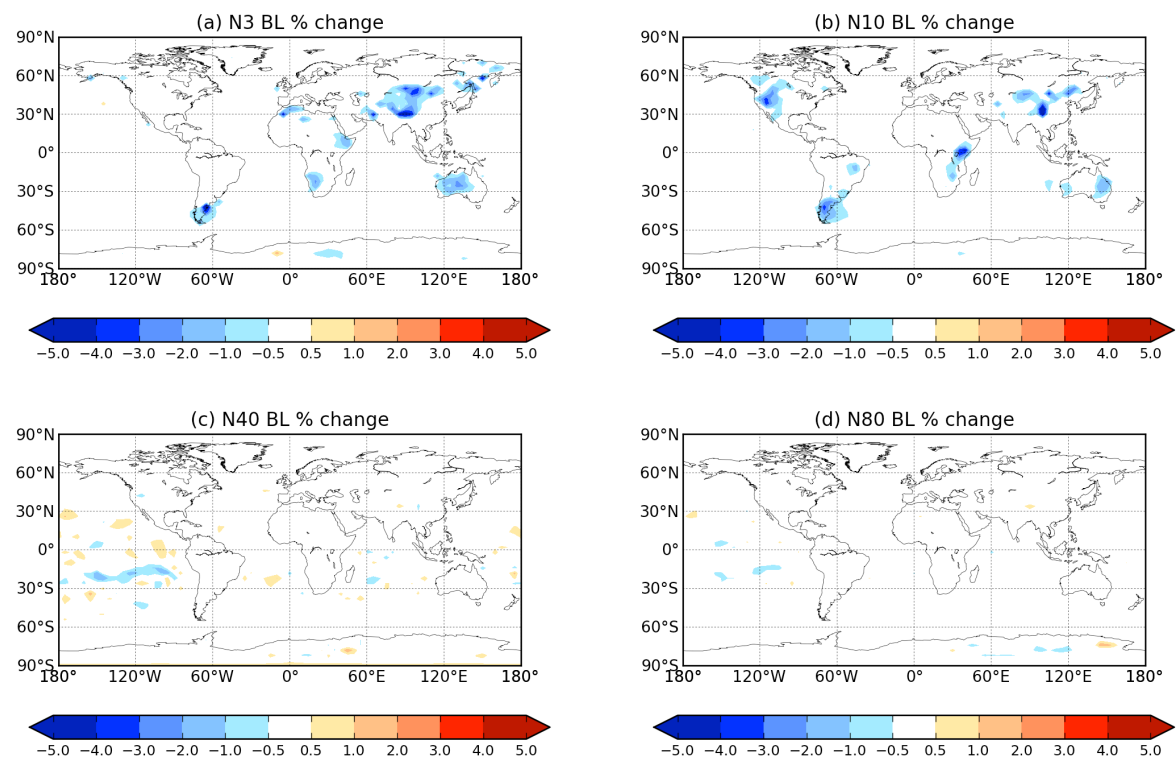

Fig. 6. Global annual-mean BL changes in (a) N3, (b) N10, (c) N40 and (d) N80 between SURF-XSOA and SURF-XSOA-K (red denotes higher concentrations in the SURF-XSOA-K simulation). There was a global BL decrease of $0.20 \%, 0.21 \%, 0.03 \%$ and $0.01 \%$ in N3, N10, $\mathrm{N} 40$ and N80 respectively when the linear sub-2.5 nm growth rate parameterization was included (Kuang et al., 2012).

\subsection{Analysis of annual-mean model-measurement comparisons}

Figure 8 shows the observed and simulated annual- or campaign-mean particle number size distributions for all of the locations outlined in Table 2. Included are the
MASS-BASE, SURF-BASE, MASS-XSOA and SURFXSOA cases. The two cases with sub- $20 \mathrm{~nm}$ growth rate parameterizations (SURF-XSOA-K and SURF-XSOA-H) had small changes from the SURF-XSOA case and thus were not included here. The base-case simulations with biogenic SOA emissions only (MASS-BASE and SURF-BASE), 

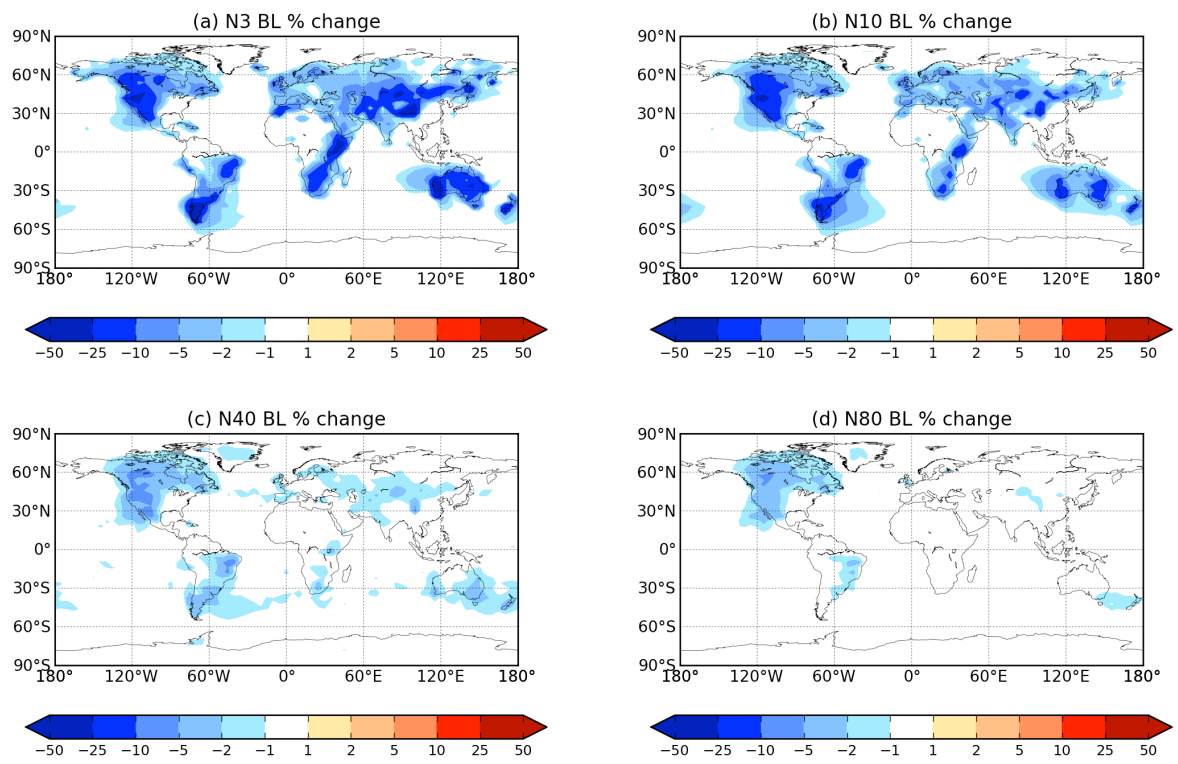

Fig. 7. Global annual-mean BL changes in (a) N3, (b) N10, (c) N40 and (d) N80 between SURF-XSOA and SURF-XSOA-H (red denotes higher concentrations in the SURF-XSOA-H simulation). There was a global BL decrease of 5.8 \%, 4.4\%, $1.0 \%$ and $0.6 \%$ in N3, N10, N40 and N80 respectively when the semi-empirical sub-20 nm growth rate parameterization was included (Häkkinen et al., 2013).

overestimate the number of particles in the nucleation mode and lower-Aitken mode $\left(D_{\mathrm{p}}<10 \mathrm{~nm}\right)$ and underestimate the number of CCN sized particles $\left(D_{\mathrm{p}}>40 \mathrm{~nm}\right)$ when compared to measurements at nearly every site. However, with the addition of the $100 \mathrm{Tg}(\mathrm{SOA}) \mathrm{yr}^{-1}$ (MASS-XSOA and SURFXSOA), the increase in condensable material causes growth and removal of the ultrafine particles and hence shift the aerosol size distributions towards increasing $\mathrm{CCN}$-sized particles and reducing the numbers of ultrafine particles (as described in Sect. 3.1).

To quantitatively compare the annual-mean modelmeasurement comparisons, we use the statistics described in Sect. 2.3. Figure 9 shows 1:1 plots for the measured and simulated annual-mean N10, N40, N80 and N150 for the MASS-BASE, SURF-BASE, MASS-XSOA and SURFXSOA cases. N150 was included in this figure since the additional SOA and changes in the condensational behavior of SOA caused significant changes to the number of particles larger than $150 \mathrm{~nm}$. This change in N150 had a large impact on the shape of the size distribution. In contrast, N3 in size distribution shape analysis behaves enough like N10 and with most of the observations starting around $10 \mathrm{~nm}, \mathrm{~N} 3$ was removed from the model-measurement analysis. Similar to Fig. 9, the two cases with sub- $20 \mathrm{~nm}$ growth rate parameterizations (SURF-XSOA-K and SURF-XSOA-H) were withheld from this figure because of their similarity to the SURFXSOA case. On each panel, the LMB, slope of the linear regression $(m)$ and coefficient of determination $\left(R^{2}\right)$ between each ground site, $i$, are labeled, and the dashed lines indicate the $5: 1$ and $1: 5$ lines. Table 3 summarizes the LMB, slope of the linear regression $(m)$ and coefficient of determination $\left(R^{2}\right)$ between each ground site, $i$, and simulation mean number concentrations in the BL. Number concentrations for N10 are consistently overestimated in the model, with MASSBASE and SURF-BASE having the highest overestimations (LMB $=0.203$ or a factor of about 1.6 for both simulations). With the additional SOA, the large positive bias in N10 in the simulations was decreased, the MASS-XSOA simulation improved to $\mathrm{LMB}=0.100$ (or a factor of 1.3). However, with kinetic SOA condensation and the additional SOA in the SURF-XSOA simulation, the bias in N10 improved further to LMB $=-0.030$ (or a factor of 0.93). The SURFXSOA simulation with the lowest LMB had a poorer regression slope ( 0.888 vs. $\sim 1$ for the others) and nearly identical $R^{2}(0.89$ vs. $\sim 0.91)$ for N10. The reduction in slope is likely related to more-polluted sites having a greater effect from the extra SOA (greater suppression of small particles). However, across the three metrics, it appears the SURF-XSOA case performs the best due to the large reduction of the bias. For number concentrations of N40, which is our proxy for small CCN, all simulations had a very small low bias (magnitude of LMB $\leq 0.067$ ). For N40, SURF-XSOA had the best slope and all simulations had equal $R^{2}$. For N80, SURFXSOA has a slight high bias $(\mathrm{LMB}=0.005)$ while the others are biased low by a larger magnitude. SURF-XSOA has the most favorable conditions for the growth of ultrafine particles to larger sizes, and this shows in this metric. SURFXSOA does significantly better for the slope of N80 than the other simulations while having similar $R^{2}$ as the other simulations. SURF-XSOA does even better for N150 (the number 


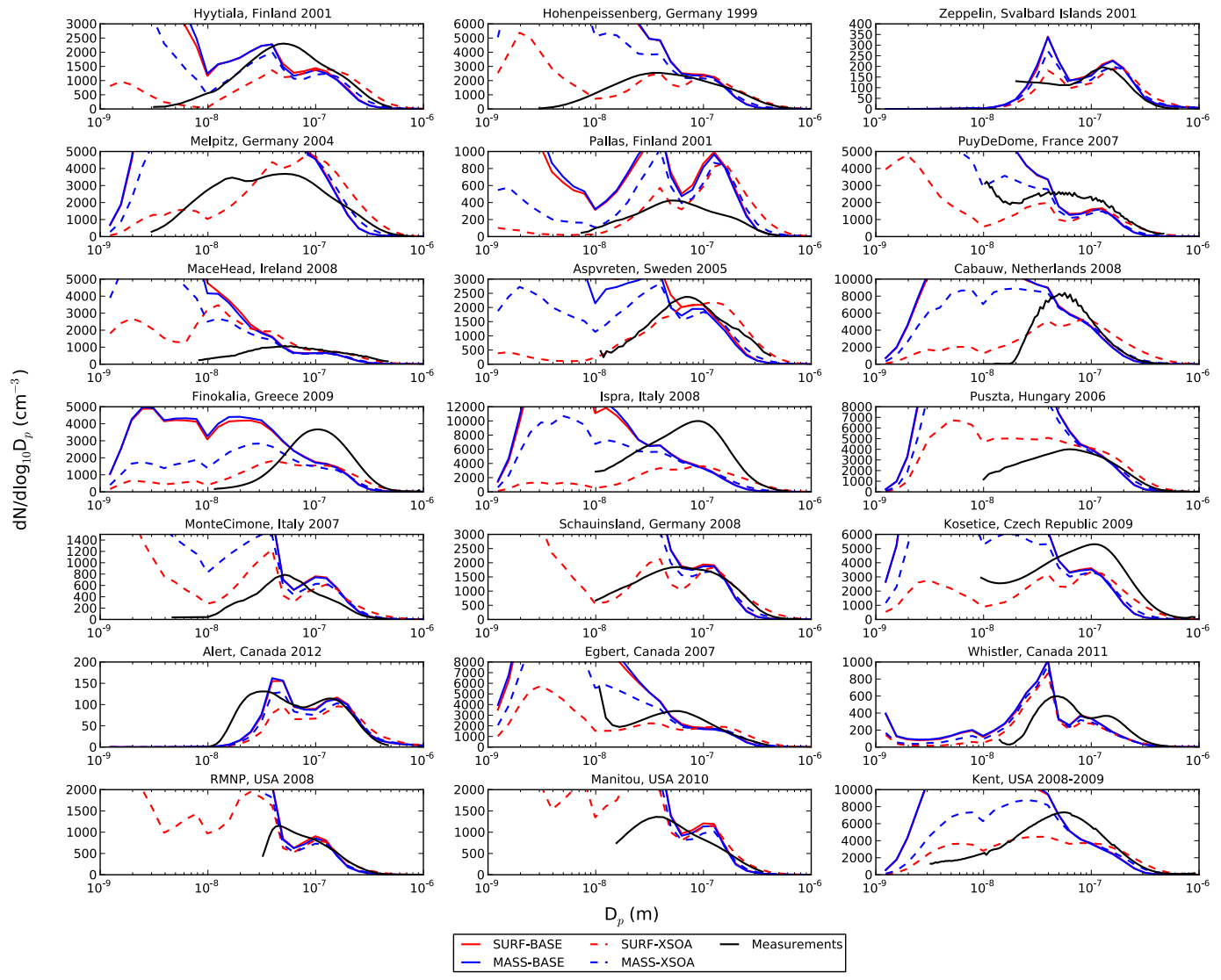

Fig. 8. Observed and simulated annual- and campaign-mean particle number size distributions for the global sites outlined in Table 2. The simulations with sub-20 nm growth rate parameterizations (SURF-XSOA-K and SURF-XSOA-H) had small changes from the SURF-XSOA case and were thus withheld from this figure.

concentration of particles with diameters larger than $150 \mathrm{~nm}$ ) with a smaller bias, better slope and slightly better $\mathrm{R}^{2}$ than the other simulations.

There is a significant improvement in most metrics when the additional SOA was included (i.e. from MASS-BASE to MASS-XSOA); however, there is also a significant improvement in all metrics when kinetic condensation was assumed instead of thermodynamic condensation (i.e. MASS-BASE to SURF-BASE). This indicates that both the amount and condensational behavior of SOA are important in order to accurately represent size distributions. However, it appears that the SURF-XSOA case generally performs the best with lower biases, better slopes overall, and similar coefficient of determinations $\left(R^{2}\right)$ for all size cutoffs. This conclusion is evidence that kinetic SOA condensation with extra, anthropogenically influenced SOA improves aerosol size distributions in models. However, we must stress that the N10, N40, N80 and N150 could be wrong or right for many reasons other than the SOA assumptions tested here. For example, the size distributions have all been shown to be sensitive to uncertainties to nucleation (Merikanto et al., 2009; Pierce and Adams, 2009a; Reddington et al., 2011; Spracklen et al.,
2008; Wang and Penner, 2009), primary emissions (Adams and Seinfeld, 2003; Pierce and Adams, 2006, 2009b; Reddington et al., 2011; Spracklen et al., 2011a), wet/dry deposition (Croft et al., 2012) and other factors (Lee et al., 2013). A recent global model uncertainty study by Lee et al. (2013) finds that the relative uncertainties to global mean $\mathrm{CCN}$ number concentrations vary between model parameters. The relative uncertainty to CCN (from $-2 \sigma$ to $2 \sigma$ ) due to accumulation mode dry deposition, Aitken mode dry deposition, anthropogenic SOA emissions, biogenic SOA emissions and boundary layer nucleation are approximately $40 \%$, $18 \%, 20 \%, 12 \%$ and $5 \%$ respectively (Lee et al., 2013). Additionally, the sub-grid-scale variability in the aerosol size distribution that is not resolved within the coarse grid boxes will result in error in our comparisons.

\section{Conclusions}

In this study we have tested the sensitivity of the global aerosol microphysics model GEOS-Chem-TOMAS to the amount and condensational behavior of secondary organic 

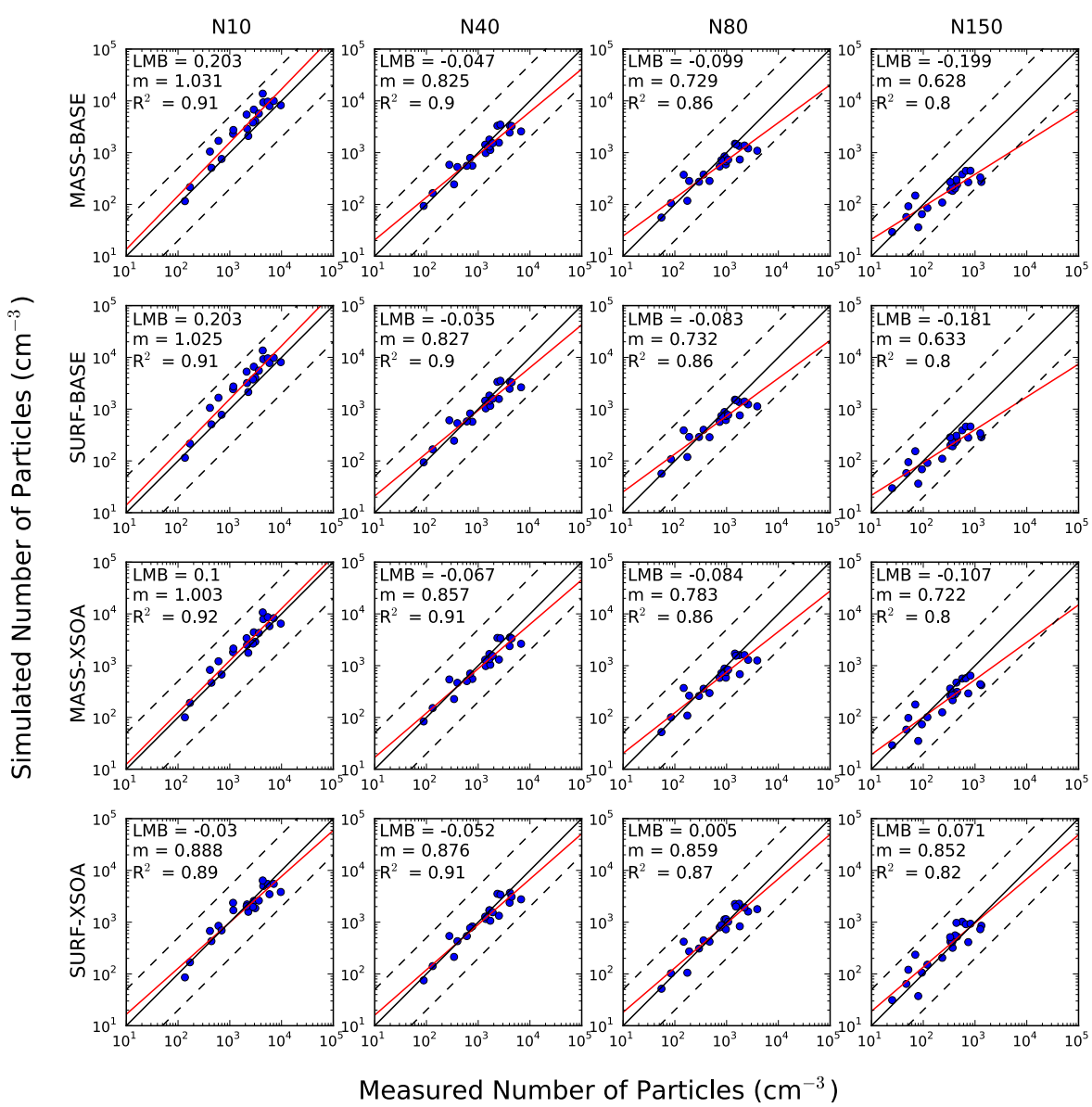

Fig. 9. $1: 1$ plots for measured and simulated annual-mean N10, N40, N80 and N150 (the total number of particles with diameter larger than $150 \mathrm{~nm})$, calculated log-mean bias (LMB), slope of the linear regression $(m)$, and correlation $\left(R^{2}\right)$. The dashed black lines indicate $5: 1$ and $1: 5$ lines. The simulations with the sub-20 nm growth rate parameterizations (SURF-XSOA-K and SURF-XSOA-H) were withheld from this figure. A summary of the statistics is compiled in Table 3.

aerosol (SOA) in order to more accurately predict the number concentration of cloud condensation nuclei (CCN) sized particles. The model output was then evaluated against groundbased measurements to test which assumption yielded the most accurate results.

An additional $100 \mathrm{Tg}(\mathrm{SOA}) \mathrm{yr}^{-1}$ spatially correlated with anthropogenic carbon monoxide (CO) emissions was then added to the model consistent with Spracklen et al. (2011b) and Heald et al. (2011). The addition of the $100 \mathrm{Tg}(\mathrm{SOA}) \mathrm{yr}^{-1}$ (assumed to be non-volatile) increased global boundary-layer (BL) N40 (particles with $D_{\mathrm{p}}>40 \mathrm{~nm}$, our proxy for small-sized CCN in this study) by $13.7 \%$ from the biogenic SOA source only simulation.

When assuming low-volatility SOA with condensation proportional to the aerosol mass distribution, or "thermodynamic condensation" as per Riipinen et al. (2011), condensation of SOA was preferential to accumulation mode particles (Pierce et al., 2011; Riipinen et al., 2011). This caused an increase in accumulation and coarse mode particles and an underestimate of N40. The assumption of non-volatile
SOA with condensation proportional to the Fuchs-corrected aerosol surface area, or "kinetic condensation" as per Riipinen et al. (2011), caused preferential condensation of SOA to ultrafine particles relative to "thermodynamic condensation" (Donahue et al., 2011; Pierce et al., 2011; Riipinen et al., 2011). This in turn grew ultrafine particles quickly and increased $\mathrm{N} 40$. When assuming kinetic condensation, the global change in BL N40 compared to assuming thermodynamic condensation yielded an increase of $10.8 \%$.

Two size-dependent growth rate parameterizations were also implemented. The first parameterization involved the condensation rate of SOA to be scaled down from the kinetic limit for particles with $D_{\mathrm{p}}$ of $1 \mathrm{~nm}$ to $2.5 \mathrm{~nm}$ based on their diameter with a linear increase in growth rate from 1 to $2.5 \mathrm{~nm}$ sized particles as per Kuang et al. (2012). The second parameterization included semi-empirical sizedependent growth rate factors for three ranges of particles of sizes $1.5 \mathrm{~nm}$ to $20 \mathrm{~nm}$ as per Häkkinen et al. (2013). The sub- $2.5 \mathrm{~nm}$ growth rate parameterization based on Kuang et al. (2012) yielded a $-0.03 \%$ global change in BL N40. The 
sub-20 nm semi-empirical growth rate parameterization from Häkkinen et al. (2013) yielded a $-1.0 \%$ global change in BL $\mathrm{N} 40$, however there were regions with decreases in BL N40 greater than $50 \%$. The global BL effects of these growth rate parameterizations, however, are within other uncertainties in the model as discussed in Sect. 3.4.

From statistical analysis, the assumption of kinetic condensation of SOA combined with the additional SOA spatially correlated with anthropogenic $\mathrm{CO}$ emissions performed the best across measurement sites for nearly all statistical metrics. However, the spatial resolution of this version of GEOS-Chem-TOMAS is much too large to resolve specific site characteristics. Therefore, it is expected that with grid boxes on the order of hundreds of kilometers, it may be difficult and impractical to tune the model on a site-specific basis.

While metrics such as primary emission, nucleation schemes and deposition all carry significant errors, this study has shown the importance of various assumptions regarding organic aerosol (amount and condensational behavior of SOA) in global microphysics models, and the influence that SOA can have on global particle size distributions. It is therefore important that these factors are appropriately included in order to provide further insights into the effect of organic aerosol on climatically relevant particles. Future studies could use size-resolved composition from state of the art instruments to further constrain SOA; it is important to not only get the size distribution correct, but it is important to get the composition correct too. More sophisticated SOA schemes involving SOA volatility and chemistry may further improve size distributions; however, combining these SOA schemes with aerosol microphysics is computationally expensive. Additionally, because SOA is also involved in aerosol nucleation (Metzger et al., 2010), the uncertainties in $\mathrm{CCN}$ due to SOA presented here are likely underestimated; however, a recent study (Scott et al., 2013) shows that uncertainties in CCN due to the SOA contribution to growth are greater than that of the SOA contribution to nucleation.

Acknowledgements. We thank the Atlantic Computational Excellence Network (ACENet) for the computational resources used in this study. The authors acknowledge Natural Sciences and Engineering Research Council (NSERC) of Canada for funding through the Network on Climate and Aerosols (NETCARE) network. We are grateful to A. M. Macdonald, S. Sharma and D. Toom-Sauntry for their support of the aerosol measurements at Whistler and Alert, and we acknowledge financial support from Environment Canada's Clean Air and Regulatory Agenda. We would also like to thank S. Lee for support of the aerosol measurements at Kent State University.

Edited by: B. Ervens

\section{References}

Aalto, P. P., Hämeri, K., Becker, E., Weber, R., Salm, J., Mäkelä, M., Hoell, J. M., O’Dowd, C., Karlsson, C. D., Hansson, H., Väkevä, H-C., Koponen, I., Buzorius, G., and Kulmala, M.: Physical characteristics of aerosol particles during nucleation events, Tellus B, 53, 344-345, 2001.

Adams, P. J. and Seinfeld, J. H.: Disproportionate impact of particulate emissions on global cloud condensation nuclei concentrations, Geophys. Res. Lett., 30, 1210-1239, doi:10.1029/2002GL016303, 2003.

Asmi, A., Wiedensohler, A., Laj, P., Fjaeraa, A.-M., Sellegri, K., Birmili, W., Weingartner, E., Baltensperger, U., Zdimal, V., Zikova, N., Putaud, J.-P., Marinoni, A., Tunved, P., Hansson, H.C., Fiebig, M., Kivekäs, N., Lihavainen, H., Asmi, E., Ulevicius, V., Aalto, P. P., Swietlicki, E., Kristensson, A., Mihalopoulos, N., Kalivitis, N., Kalapov, I., Kiss, G., de Leeuw, G., Henzing, B., Harrison, R. M., Beddows, D., O’Dowd, C., Jennings, S. G., Flentje, H., Weinhold, K., Meinhardt, F., Ries, L., and Kulmala, M.: Number size distributions and seasonality of submicron particles in Europe 2008-2009, Atmos. Chem. Phys., 11, 5505-5538, doi:10.5194/acp-11-5505-2011, 2011.

Charlson, R. J., Schwartz, S. E., Hales, J. M., Cess, R. D., Coakley, J. A., Hansen, J. E., and Hofmann, D. J.: Climate forcing by anthropogenic aerosols, Science, 255, 423-430, 1992.

Clement, A. C., Burgman, R., and Norris, J. R.: Observational and Model Evidence for Positive Low-Level Cloud Feedback, Science, 325, 460-464, 2009.

Croft, B., Pierce, J. R., Martin, R. V., Hoose, C., and Lohmann, U.: Uncertainty associated with convective wet removal of entrained aerosols in a global climate model, Atmos. Chem. Phys., 12, 10725-10748, doi:10.5194/acp-12-10725-2012, 2012.

Donahue, N. M., Trump, E. R., Pierce, J. R., and Riipinen, I.: Theoretical constraints on pure vapor-pressure driven condensation of organics to ultrafine particles, Geophys. Res. Lett., 38, L16801, doi:10.1029/2011GL048115, 2011.

Dusek, U., Frank, G. P., Hildebrandt, L., Curtius, J., Schneider, J., Walter, S., Chand, D., Drewnick, F., Hings, S., Jung, D., Borrmann, S., and Andreae, M. O.: Size Matters More Than Chemistry for Cloud-Nucleating Ability of Aerosol Particles, Science, 312, 1375-1378, 2006.

Erupe, M. E., Benson, D. R., Li, J., Young, L.-H., Verheggen, B., Al-Refai, M., Tahboub, O., Cunningham, V., Frimpong, F., Viggiano, A. A., and Lee, S.-H.: Correlation of Aerosol Nucleation Rate with Sulfuric Acid and Ammonia in Kent Ohio: An Atmospheric Observation, J. Geophys. Res., 115, D23216, doi:10.1029/2005GL023268, 2010.

Goldstein, A. H. and Gallbaly, I. E.: Known and unexplored organic constituents in the Earth's Atmosphere, Environ Sci. Technol., 41, 1514-1521, 2007.

Häkkinen, S. A. K., Manninen, H. E., Yli-Juuti, T., Merikanto, J., Kajos, M. K., Nieminen, T., D’Andrea, S. D., Asmi, A., Pierce, J. R., Kulmala, M., and Riipinen, I.: Semi-empirical parameterization of size-dependent atmospheric nanoparticle growth in continental environments, Atmos. Chem. Phys., 13, 7665-7682, doi:10.5194/acp-13-7665-2013, 2013.

Hallquist, M., Wenger, J. C., Baltensperger, U., Rudich, Y., Simpson, D., Claeys, M., Dommen, J., Donahue, N. M., George, C., Goldstein, A. H., Hamilton, J. F., Herrmann, H., Hoffmann, T., Iinuma, Y., Jang, M., Jenkin, M. E., Jimenez, J. L., 
Kiendler-Scharr, A., Maenhaut, W., McFiggans, G., Mentel, Th. F., Monod, A., Prévôt, A. S. H., Seinfeld, J. H., Surratt, J. D., Szmigielski, R., and Wildt, J.: The formation, properties and impact of secondary organic aerosol: current and emerging issues, Atmos. Chem. Phys., 9, 5155-5236, doi:10.5194/acp-9-51552009, 2009.

Heald, C. L., Coe, H., Jimenez, J. L., Weber, R. J., Bahreini, R., Middlebrook, A. M., Russell, L. M., Jolleys, M., Fu, T.-M., Allan, J. D., Bower, K. N., Capes, G., Crosier, J., Morgan, W. T., Robinson, N. H., Williams, P. I., Cubison, M. J., DeCarlo, P. F., and Dunlea, E. J.: Exploring the vertical profile of atmospheric organic aerosol: comparing 17 aircraft field campaigns with a global model, Atmos. Chem. Phys., 11, 12673-12696, doi:10.5194/acp-11-12673-2011, 2011.

Jimenez, J. L., Canagaratna, M. R., Donahue, N. M., Prevot, A. S. H., Zhang, Q., Kroll, J. H., DeCarlo, P. F., Allan, J. D., Coe, H., Ng, N. L., Aiken, A. C., Docherty, K. S., Ulbrich, I. M., Grieshop, A. P., Robinson, A. L., Duplissy, J., Smith, J. D., Wilson, K. R., Lanz, V. A., Hueglin, C., Sun, Y. L., Tian, J., Laaksonen, A., Raatikainen, T., Rautiainen, J., Vaattovaara, P., Ehn, M., Kulmala, M., Tomlinson, J. M., Collins, D. R., Cubison, M. J., Dunlea, E. J., Huffman, J. A., Onasch, T. B., Alfarra, M. R., Williams, P. I., Bower, K., Kondo, Y., Schneider, J., Drewnick, F., Borrmann, S., Weimer, S., Demerjian, K., Salcedo, D., Cottrell, L., Griffin, R., Takami, A., Miyoshi, T., Hatakeyama, S., Shimono, A., Sun, J. Y., Zhang, Y. M., Dzepina, K., Kimmel, J. R., Sueper, D., Jayne, J. T., Herndon, S. C., Trimborn, A. M., Williams, L. R., Wood, E. C., Middlebrook, A. M., Kolb, C. E., Baltensperger, U., and Worsnop, D. R.: Evolution of organic aerosols in the atmosphere, Science, 326, 1525-1529, doi:10.1126/science.1180353, 2009.

Jung, J., Fountoukis, C., Adams, P. J., and Pandis, S. N.: Simulation of in situ ultrafine particle formation in the eastern United States using PMCAMx-UF, J. Geophys. Res., 115, D03203, doi:10.1029/2009JD012313, 2010.

Kanakidou, M., Seinfeld, J. H., Pandis, S. N., Barnes, I., Dentener, F. J., Facchini, M. C., Van Dingenen, R., Ervens, B., Nenes, A., Nielsen, C. J., Swietlicki, E., Putaud, J. P., Balkanski, Y., Fuzzi, S., Horth, J., Moortgat, G. K., Winterhalter, R., Myhre, C. E. L., Tsigaridis, K., Vignati, E., Stephanou, E. G., and Wilson, J.: Organic aerosol and global climate modelling: a review, Atmos. Chem. Phys., 5, 1053-1123, doi:10.5194/acp-5-1053-2005, 2005.

Kanawade, V. P., Benson, D. R., and Lee, S.-H.: Statistical analysis of 4-year observations of aerosol sizes in a semi-rural continental environment, Atmos. Environ., 59, 30-38, 2012.

Kerminen, V.-M. and Kulmala, M.: Analytical formulae connecting the "real" and the "apparent" nucleation rate and the nuclei number concentration for atmospheric nucleation events, J. Aerosol Sci., 33, 609-622, 2002.

Kuang, C., McMurry, P. H., and McCormick, A. V: Determination of cloud condensation nuclei production from measured new particle formation events, Geophys. Res. Lett., 36, doi:10.1029/2009GL037584, 2009.

Kuang, C., Chen, M., Zhao, J., Smith, J., McMurry, P. H., and Wang, J.: Size and time-resolved growth rate measurements of 1 to 5 $\mathrm{nm}$ freshly formed atmospheric nuclei, Atmos. Chem. Phys., 12, 3573-3589, doi:10.5194/acp-12-3573-2012, 2012.
Kulmala, M., Vehkamäki, H., Petäjä, T., Dal Maso, M., Lauri, A., Kerminen, V.-M., Birmili, W., and McMurry, P. H.: Formation and growth of ultrafine atmospheric particles: A review of observations, J. Aerosol Sci., 35, 143-176, 2004.

Lane, T. E. and Pandis, S. N.: Predicted secondary organic aerosol concentrations from the oxidation of isoprene in the Eastern United States, Environ. Sci. Technol., 41, 3984-3990, 2007.

Leaitch, W. R., Sharma, S., Huang, L., Macdonald, A. M., ToomSauntry, D., Chivulescu, A., von Salzen, K., Pierce, J. R., Shantz, N. C., Bertram, A., Schroder, J., Norman, A.-L., and Change, R. Y.-W.: Dimethyl Sulphide Control of the Clean Summertime Arctic Aerosol and Cloud, Elementa: Science of the Anthropocene, submitted, 2013.

Lee, L. A., Pringle, K. J., Reddington, C. L., Mann, G. W., Stier, P., Spracklen, D. V., Pierce, J. R., and Carslaw, K. S.: The magnitude and causes of uncertainty in global model simulations of cloud condensation nuclei, Atmos. Chem. Phys., 13, 8879-8914, doi:10.5194/acp-13-8879-2013, 2013.

Levin, E. J. T., Kreidenweis, S. M., McMeeking, G. R., Carrico, C. M., Collett Jr., J. L., and Malm, W. C.: Aerosol physical, chemical and optical properties during the Rocky Mountain Airborne Nitrogen and Sulfur study, Atmos. Environ., 43, 19321939, doi:10.1016/j.atmosenv.2008.12.042, 2009.

Levin, E. J. T., Prenni, A. J., Petters, M. D., Kreidenweis, S. M., Sullivan, R. C., Atwood, S. A., Ortega, J., DeMott, P. J., and Smith, J. N.: An annual cycle of size-resolved aerosol hygroscopicity at a forested site in Colorado, J. Geophys, Res., 117, D06201, doi:10.1029/2011JD016854, 2012.

Manninen, H. E., Nieminen, T., Asmi, E., Gagné, S., Häkkinen, S., Lehtipalo, K., Aalto, P., Vana, M., Mirme, A., Mirme, S., Hõrrak, U., Plass-Dülmer, C., Stange, G., Kiss, G., Hoffer, A., Törõ, N., Moerman, M., Henzing, B., de Leeuw, G., Brinkenberg, M., Kouvarakis, G. N., Bougiatioti, A., Mihalopoulos, N., O'Dowd, C., Ceburnis, D., Arneth, A., Svenningsson, B., Swietlicki, E., Tarozzi, L., Decesari, S., Facchini, M. C., Birmili, W., Sonntag, A., Wiedensohler, A., Boulon, J., Sellegri, K., Laj, P., Gysel, M., Bukowiecki, N., Weingartner, E., Wehrle, G., Laaksonen, A., Hamed, A., Joutsensaari, J., Petäjä, T., Kerminen, V.-M., and Kulmala, M.: EUCAARI ion spectrometer measurements at 12 European sites - analysis of new particle formation events, Atmos. Chem. Phys., 10, 7907-7927, doi:10.5194/acp-10-79072010, 2010.

McFiggans, G., Artaxo, P., Baltensperger, U., Coe, H., Facchini, M. C., Feingold, G., Fuzzi, S., Gysel, M., Laaksonen, A., Lohmann, U., Mentel, T. F., Murphy, D. M., O’Dowd, C. D., Snider, J. R., and Weingartner, E.: The effect of physical and chemical aerosol properties on warm cloud droplet activation, Atmos. Chem. Phys., 6, 2593-2649, doi:10.5194/acp-6-2593-2006, 2006.

Merikanto, J., Spracklen, D. V., Mann, G. W., Pickering, S. J., and Carslaw, K. S.: Impact of nucleation on global CCN, Atmos. Chem. Phys., 9, 8601-8616, doi:10.5194/acp-9-8601-2009, 2009.

Metzger, A., Verheggen, B., Dommen, J., Duplissy, J., Prevot, A. S. H., Weingartner, E., Riipinen, I., Kulmala, M., Spracklen, D. V., Carslaw, K. S., and Baltensperger, U.: Atmospheric Chemistry Special Feature: Evidence for the role of organics in aerosol particle formation under atmospheric conditions, Proc. Natl. Acad. Sci., 107, 6646-6651, doi:10.1073/pnas.0911330107, 2010. 
Napari, I., Noppel, M., Vehkamäki, H., and Kulmala, M.: Parametrization of ternary nucleation rates for $\mathrm{H}_{2} \mathrm{SO}_{4}-\mathrm{NH}_{3}-$ $\mathrm{H}_{2} \mathrm{O}$ vapors, J. Geophys. Res.-Atmos., 107, AAC 6-1-AAC 6-6, doi:10.1029/2002JD002132, 2002.

Pankow, J. F.: An absorption model of gas/particle partitioning of organic compounds in the atmosphere, Atmos. Environ., 28, 185-188, 1994.

Petters, M. D. and Kreidenweis, S. M.: A single parameter representation of hygroscopic growth and cloud condensation nucleus activity, Atmos. Chem. Phys., 7, 1961-1971, doi:10.5194/acp-71961-2007, 2007.

Pierce, J. R. and Adams, P. J.: Global evaluation of CCN formation by direct emission of sea salt and growth of ultrafine sea salt, J. Geophys. Res.-Atmos., 111, D06203, doi:10.1029/2005JD006186, 2006.

Pierce, J. R. and Adams, P. J.: Efficiency of cloud condensation nuclei formation from ultrafine particles, Atmos. Chem. Phys., 7, 1367-1379, doi:10.5194/acp-7-1367-2007, 2007.

Pierce, J. R. and Adams, P. J.: A Computationally Efficient Aerosol Nucleation/Condensation Method: PseudoSteady-State Sulfuric Acid, Aerosol Sci. Tech., 43, 216-226, doi:10.1080/02786820802587896, 2009a.

Pierce, J. R. and Adams, P. J.: Uncertainty in global CCN concentrations from uncertain aerosol nucleation and primary emission rates, Atmos. Chem. Phys., 9, 1339-1356, doi:10.5194/acp-91339-2009, 2009b.

Pierce, J. R., Riipinen, I., Kulmala, M., Ehn, M., Petäjä, T., Junninen, H., Worsnop, D. R., and Donahue, N. M.: Quantification of the volatility of secondary organic compounds in ultrafine particles during nucleation events, Atmos. Chem. Phys., 11, 90199036, doi:10.5194/acp-11-9019-2011, 2011.

Pierce, J. R., Leaitch, W. R., Liggio, J., Westervelt, D. M., Wainwright, C. D., Abbatt, J. P. D., Ahlm, L., Al-Basheer, W., Cziczo, D. J., Hayden, K. L., Lee, A. K. Y., Li, S.-M., Russell, L. M., Sjostedt, S. J., Strawbridge, K. B., Travis, M., Vlasenko, A., Wentzell, J. J. B., Wiebe, H. A., Wong, J. P. S., and Macdonald, A. M.: Nucleation and condensational growth to $\mathrm{CCN}$ sizes during a sustained pristine biogenic SOA event in a forested mountain valley, Atmos. Chem. Phys., 12, 3147-3163, doi:10.5194/acp-12-3147-2012, 2012.

Pierce, J. R., Evans, M. J., Scott, C. E., D’Andrea, S. D., Farmer, D. K., Swietlicki, E., and Spracklen, D. V.: Weak global sensitivity of cloud condensation nuclei and the aerosol indirect effect to Criegee $+\mathrm{SO}_{2}$ chemistry, Atmos. Chem. Phys., 13, 3163-3176, doi:10.5194/acp-13-3163-2013, 2013.

Reddington, C. L., Carslaw, K. S., Spracklen, D. V., Frontoso, M. G., Collins, L., Merikanto, J., Minikin, A., Hamburger, T., Coe, H., Kulmala, M., Aalto, P., Flentje, H., Plass-Dülmer, C., Birmili, W., Wiedensohler, A., Wehner, B., Tuch, T., Sonntag, A., O’Dowd, C. D., Jennings, S. G., Dupuy, R., Baltensperger, U., Weingartner, E., Hansson, H.-C., Tunved, P., Laj, P., Sellegri, K., Boulon, J., Putaud, J.-P., Gruening, C., Swietlicki, E., Roldin, P., Henzing, J. S., Moerman, M., Mihalopoulos, N., Kouvarakis, G., Ždímal, V., Zíková, N., Marinoni, A., Bonasoni, P., and Duchi, R.: Primary versus secondary contributions to particle number concentrations in the European boundary layer, Atmos. Chem. Phys., 11, 12007-12036, doi:10.5194/acp-11-12007-2011, 2011.

Riipinen, I., Pierce, J. R., Yli-Juuti, T., Nieminen, T., Häkkinen, S., Ehn, M., Junninen, H., Lehtipalo, K., Petäjä, T., Slowik, J.,
Chang, R., Shantz, N. C., Abbatt, J., Leaitch, W. R., Kerminen, V.-M., Worsnop, D. R., Pandis, S. N., Donahue, N. M., and Kulmala, M.: Organic condensation: a vital link connecting aerosol formation to cloud condensation nuclei (CCN) concentrations, Atmos. Chem. Phys., 11, 3865-3878, doi:10.5194/acp-11-38652011, 2011.

Rosenfeld, D., Lohmann, U., Raga, G. B., O’Dowd, C. D., Kulmala, M., Fuzzi, S., Reissell, A., and Andreae, M. O.: Flood or Drought: How Do Aerosols Affect Precipitation?, Science, 312, 1309-1313, 2008.

Scott, C. E., Rap, A., Spracklen, D. V., Forster, P. M., Carslaw, K. S., Mann, G. W., Pringle, K. J., Kivekäs, N., Kulmala, M., Lihavainen, H., and Tunved, P.: The direct and indirect radiative effects of biogenic secondary organic aerosol, Atmos. Chem. Phys. Discuss., submitted, 2013.

Sipilä, M., Berndt, T., Petäjä, T., Brus, D., Vanhanen, J., Stratmann, F., Patokoski, J., Mauldin III, R. L., Hyvärinen, A.-P., Lihavainen, H., and Kulmala, M.: Role of Sulfuric Acid in Atmospheric Nucleation, Science, 327, 1243-1246, 2010.

Spracklen, D. V., Carslaw, K. S., Kulmala, M., Kerminen, V.-M., Mann, G. W., and Sihto, S.-L.: The contribution of boundary layer nucleation events to total particle concentrations on regional and global scales, Atmos. Chem. Phys., 6, 5631-5648, doi:10.5194/acp-6-5631-2006, 2006.

Spracklen, D. V, Carslaw, K. S., Kulmala, M., Kerminen, V. M., Sihto, S. L., Riipinen, I., Merikanto, J., Mann, G. W., Chipperfield, M. P., Wiedensohler, A., Birmili, W., and Lihavainen, H.: Contribution of particle formation to global cloud condensation nuclei concentrations, Geophys. Res. Lett., 35, D06808, doi:10.1029/2007GL033038, 2008.

Spracklen, D. V., Carslaw, K. S., Pöschl, U., Rap, A., and Forster, P. M.: Global cloud condensation nuclei influenced by carbonaceous combustion aerosol, Atmos. Chem. Phys., 11, 9067-9087, doi:10.5194/acp-11-9067-2011, 2011a.

Spracklen, D. V., Jimenez, J. L., Carslaw, K. S., Worsnop, D. R., Evans, M. J., Mann, G. W., Zhang, Q., Canagaratna, M. R., Allan, J., Coe, H., McFiggans, G., Rap, A., and Forster, P.: Aerosol mass spectrometer constraint on the global secondary organic aerosol budget, Atmos. Chem. Phys., 11, 12109-12136, doi:10.5194/acp-11-12109-2011, 2011 b.

van Donkelaar, A., Martin, R. V., Leaitch, W. R., Macdonald, A. M., Walker, T. W., Streets, D. G., Zhang, Q., Dunlea, E. J., Jimenez, J. L., Dibb, J. E., Huey, L. G., Weber, R., and Andreae, M. O.: Analysis of aircraft and satellite measurements from the Intercontinental Chemical Transport Experiment (INTEX-B) to quantify long-range transport of East Asian sulfur to Canada, Atmos. Chem. Phys., 8, 2999-3014, doi:10.5194/acp-8-2999-2008, 2008.

Vehkamäki, H. and Riipinen, I.: Thermodynamics and kinetics of atmospheric aerosol particle formation and growth, Chem. Soc. Rev., 41, 5160-5173, doi:10.1039/c2cs00002d, 2012.

Wainwright, C. D., Pierce, J. R., Liggio, J., Strawbridge, K. B., Macdonald, A. M., and Leaitch, R. W.: The effect of model spatial resolution on Secondary Organic Aerosol predictions: a case study at Whistler, BC, Canada, Atmos. Chem. Phys., 12, 1091110923, doi:10.5194/acp-12-10911-2012, 2012.

Wang, M. and Penner, J. E.: Aerosol indirect forcing in a global model with particle nucleation, Atmos. Chem. Phys., 9, 239-260, doi:10.5194/acp-9-239-2009, 2009. 
Wang, S. C. and Flagan, R. C.: Scanning Electrical Mobility Spectrometer. Aerosol Sci. Tech., 13, 230-240, 1990.

Westervelt, D. M., Pierce, J. R., Riipinen, I., Trivitayanurak, W., Hamed, A., Kulmala, M., Laaksonen, A., Decesari, S., and Adams, P. J.: Formation and growth of nucleated particles into cloud condensation nuclei: model-measurement comparison, Atmos. Chem. Phys., 13, 7645-7663, doi:10.5194/acp-13-76452013, 2013.

Yli-Juuti, T., Nieminen, T., Hirsikko, A., Aalto, P. P., Asmi, E., Hõrrak, U., Manninen, H. E., Patokoski, J., Dal Maso, M., Petäjä, T., Rinne, J., Kulmala, M., and Riipinen, I.: Growth rates of nucleation mode particles in Hyytiälä during 20032009: variation with particle size, season, data analysis method and ambient conditions, Atmos. Chem. Phys., 11, 12865-12886, doi:10.5194/acp-11-12865-2011, 2011.
Zhang, X., Pandis, S. N., and Seinfeld, J. H.: Diffusion-Limited Versus Quasi-Equilibrium Aerosol Growth, Aerosol Sci. Tech., 46, 874-885, doi:10.1080/02786826.2012.679344, 2012. 